\title{
Socioeconomic and Technical Characteristics of Broiler and Laying Hens Layers in Peri-urban and Urban Areas in the City of Dschang, West Cameroon
}

\author{
Guillaume Hensel Fongang Fouepe ${ }^{1,}$, , Jean Raphaël Kana ${ }^{2}$, Geradine Marie Djiobou Kengmo ${ }^{1}$, \\ Abdoulay Mfewou ${ }^{3}$ \\ ${ }^{1}$ Department of Agricultural Extension and Rural Sociology, University of Dschang, Dschang, Cameroon \\ ${ }^{2}$ Department of Animal Production, University of Dschang, Dschang, Cameroon \\ ${ }^{3}$ Department of Geography, University of Dschang, Dschang, Cameroon
}

Email address:

guillaumefongang@yahoo.fr (G. H. F. Fouepe)

${ }^{*}$ Corresponding author

To cite this article:

Guillaume Hensel Fongang Fouepe, Jean Raphaël Kana, Geradine Marie Djiobou Kengmo, Abdoulay Mfewou. Socioeconomic and Technical Characteristics of Broiler and Laying Hens Layers in Peri-urban and Urban Areas in the City of Dschang, West Cameroon. International Journal of Agricultural Economics. Vol. 2, No. 4, 2017, pp. 110-121. doi: 10.11648/j.ijae.20170204.13

Received: May 7, 2017; Accepted: May 18, 2017; Published: June 19, 2017

\begin{abstract}
This study assesses the socio-economic and technical characteristics of broilers and layers rearing in the urban and peri-urban areas of Dschang (West Region, Cameroon). Using a questionnaire, information was collected in 52 and 14 broilers and layers stock farming respectively in order to identify opportunities to improve the productivity of these farms. The results show that, $57.8 \%$ of broiler breeders and $64.3 \%$ of layer breeders are men. In both cases, farmers have 7 years of professional experience on average. $82.5 \%$ of broiler breeders use their house as breeding farms. $92.9 \%$ of layer breeders are owners of the farm. The herd size varied from 4000 to 10000 broilers and 2000 to 5000 layers per breeder. Broilers are sold at maturity after 45 days and layers are reformed beyond 80 weeks of age. The major constraints to the development of this sector include avian diseases, high input costs, non-respect of breeding house norms and lack of funding. In conclusion, this study recommends the establishment of appropriate funding mechanisms.
\end{abstract}

Keywords: Poultry Farming, Breeders, Characteristics, Constraints, Dschang, Cameroon

\section{Introduction}

The rapid urbanization of countries of the South have led to the creation of hybrid spaces, half town half-village, which poses food security and family farming transformations challenges [18]. The difficult global economic context is more pronounced for small producers in rural and suburban areas in sub-Saharan Africa and it requires a diversification of activities [30]. Since 1960, overall chicken production has considerably grown more than that of any other type of meat in both developed and developing countries [24]. Since the early 2000s, imports of frozen poultry from Europe and America have grown considerably in several developing countries in Africa and the Caribbean, competing with local chicken production [12]. The latter have higher production costs and an inefficient marketing system [24]. In Cameroon, since March 2005, the state has significantly regulated the quota of imported chicken, creating an increasing local demand that the local market could not satisfy [5]. Thanks to the complete cessation of frozen chicken imports in Cameroon in 2006, local producers, both large and small, have taken up the path of poultry farms with fervor and national production is booming [35].

In addition to this, interest in urban and peri-urban livestock farming has increased over the last twenty years, partly because of the rapid growth of the urban population and thus a high demand from consumers and, on the other hand, due to the dynamism of actors in different sectors [21]. The practice of urban and peri-urban agriculture has become a means of conversion or reconversion of city 
dwellers who have been victims to the vicissitudes of everyday life. Indeed, it makes it possible to counteract the difficulties linked to the deterioration of living conditions and the lack of space for agricultural production in the city [25]. In African countries, eggs and chicken are progressively and significantly contributing to relief protein deficiency in food [44]. They represent $14 \%$ of the population's protein requirements in Cameroon and generate many jobs [35]. Poultry today constitute one of a few savings opportunities [16]. In Cameroon, national consumption of chicken increased from $1.5 \mathrm{~kg} /$ inhabitant / year in 1992 to $2.4 \mathrm{~kg} /$ inhabitant / year in 2002 [9]. In 2006, it was 3 to $4 \mathrm{~kg} /$ inhabitant / year of chicken and 0.9 $\mathrm{kg} /$ inhabitant / year for eggs [36]. For the Cameroonian poultry inter-professional sector, the desire would be to reach 10 to $15 \mathrm{~kg} /$ inhabitant / year of meat, provided the standard of living of the populations is raised. To meet the annual deficit of chicken estimated at 98000 tons in 2015, an annual increase of 1.2 million chicks per year is required, with the aim of reducing imports [35]. Urban and peri-urban farming occupies an increasingly important place in the Western region of Cameroon.

These farms are marked by a great diversity of species and production systems without any rigorous assessment of their relative importance in terms of numbers, socio-economic role, number of actors involved and numbers of animals. Through market mechanisms, there is currently a surge in the price of this commodity both in towns and the countryside. The poultry sector occupies a central place in current agropastoral development in Cameroon these recent years. Globally, the poultry industry faces pressures in order to improve production techniques, especially in terms of health, environment and animal welfare [24].

This study is therefore carried out in the context of irregular production dynamics, the need to develop the production capacities of national poultry farms, but also the absence of evaluation and statistics. However, to be successful in any policy geared towards the development of the livestock sector, account should be taken as concerns the variability of production in space, bird density, access to inputs and markets, health risks and environmental requirements [40]. The aim is to upgrade knowledge on the socio-economic and technical characteristics of poultry farming in the urban and peri-urban areas of Dschang, with a view to make data available which could help in the definition of appropriate strategies for the development of modern poultry farming in Cameroon.

\section{Material and Methods}

This study was conducted in the peri-urban and urban areas of the city of Dschang. This area today represents an important avian production and consumption area. Its population has grown from 29,312 in 1997 to more than 80,000 in 2013 [8]. This rapid increase in population is due to the fact that Dschang became a university town with the 1993 university reform in Cameroon. Also, Dschang is a cultural city which welcomes many visitors. It is also the headquarter of the Menoua Division, one of eight Divisions which make up the Western Region. Menoua Division covers an area of about $368 \mathrm{~km}^{2}$ in which the town of Dschang covers about $16.5 \mathrm{~km}^{2}$. Located between latitude $5^{\circ} 25^{\prime}$ to $5^{\circ}$ $30^{\prime}$ north and longitude $10^{\circ}$ to $10^{\circ} 5^{\prime}$ East, Dschang is characterized by two seasons, a long rainy season from March to October and a short dry season from November to February. Annual precipitation ranges from 1500 to $2000 \mathrm{~mm}$ with an average of $1590 \mathrm{~mm}$, for 160 days of rain per year. The annual thermal amplitude is very low $\left(3^{\circ} \mathrm{C}\right)$ and the average temperature is $20.2^{\circ} \mathrm{C}$.

The sampling method first consisted of an inventory of the poultry farms. This was done from Semi-Structured Interviews (SSI) with resource persons and then by a snowball survey (from one breeder to another) in the periurban and urban area of the city of Dschang. We identified 94 permanent broiler farms with at least 50 subjects and 15 permanent breeders of layers with at least 500 subjects, thus a total of 109 farms. Data was collected from a sample of $55.3 \%$ of the broiler chicken farms and $93.3 \%$ of laying-hens farms. The information collected concerned the socio-professional characteristics of the farmer, the level of basic investments, zoo-technical and the marketing data of livestock products, the intensity of the activity through the size of livestock and the constraints related to the activity. The geographic coordinates of each surveyed farm was recorded with a Garmin GPS and these coordinates were introduced into Arcgis software to map the spatial distribution of the farms in the study area (Figure 1). The collected data was coded and entered into Microsoft Excel software and then exported to Statistical Package for Social Sciences (SPSS) software for descriptive statistical analyzes (frequency, mean, sum and standard deviation). 


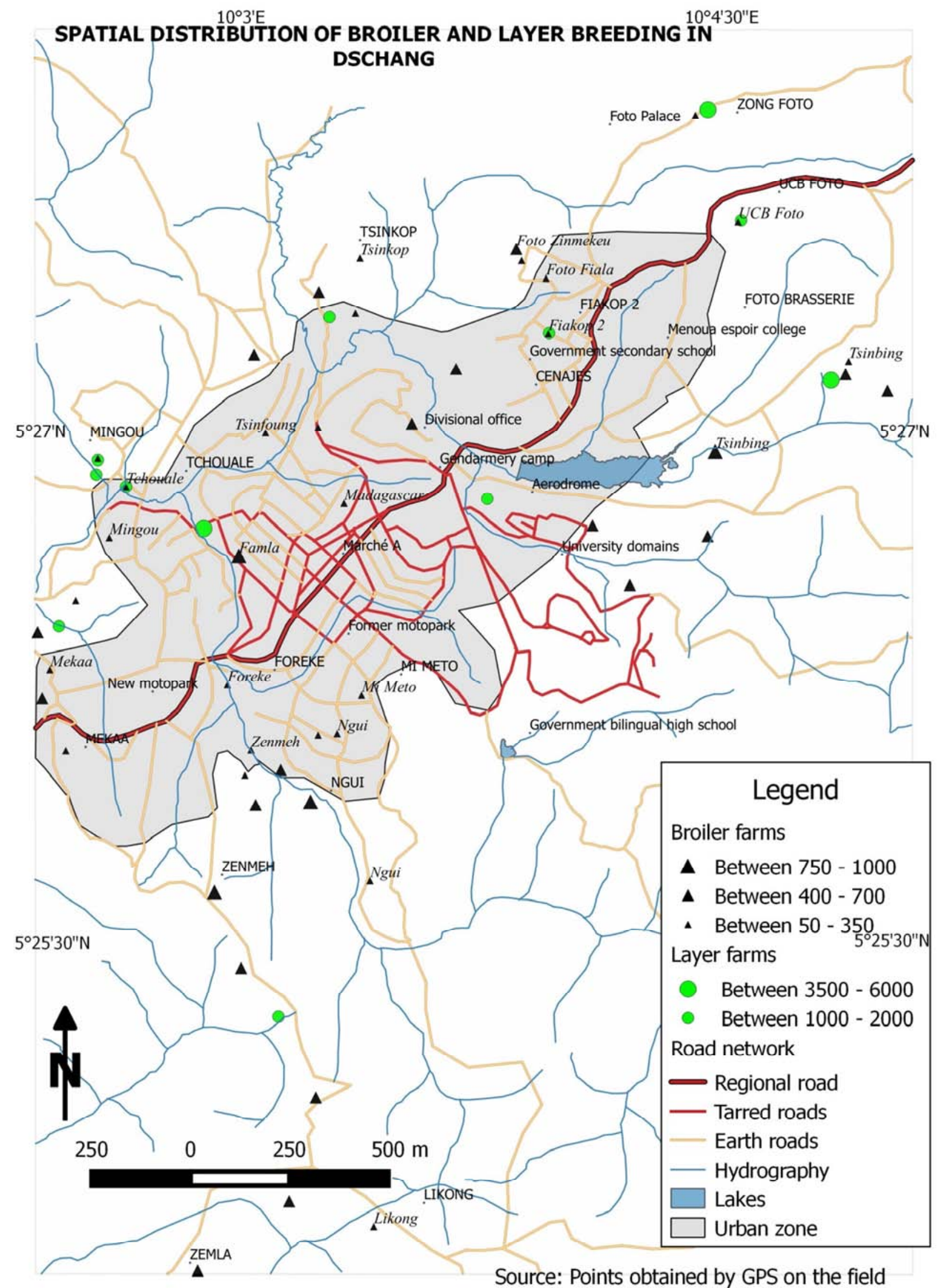

Figure 1. Spatial distribution of chicken and laying hens farms in the urban and peri-urban area of Dschang (Cameroon). 


\section{Result and Discussions}

\subsection{Socio-economic Profile of the Surveyed Breeders}

Table 1 summarizes some socio-economic characteristics of the surveyed breeders.

Table 1. A few socio-economic characteristics of surveyed rearers.

\begin{tabular}{|c|c|c|c|c|}
\hline \multirow[t]{2}{*}{ Characteristics } & \multicolumn{2}{|c|}{ Chicken breeders } & \multicolumn{2}{|c|}{ Layer breeders } \\
\hline & $\mathbf{N}$ & & $\mathbf{N}$ & \\
\hline $\begin{array}{l}\text { Mean age } \\
\text { Genre (\%) }\end{array}$ & $42 \pm 10,7$ & & $46,2 \pm 11$ & \\
\hline Male & 28 & 53,8 & 5 & 64,3 \\
\hline Female & 24 & 46,2 & 9 & 35,7 \\
\hline $\begin{array}{l}\text { Total } \\
\text { Matrimonial situation (\%) }\end{array}$ & 52 & 100 & 14 & 100 \\
\hline Married & 45 & 86,5 & 14 & 100 \\
\hline Single & 7 & 13,5 & 0 & 0 \\
\hline Widow (er) & 0 & 0 & 0 & 0 \\
\hline Total & 52 & 100 & 14 & 100 \\
\hline Matrimonial regime & & & & \\
\hline Monogamy & 34 & 75 & 14 & 100 \\
\hline Polygamy & 11 & 25 & 0 & 0 \\
\hline Total & 45 & 100 & 14 & 100 \\
\hline Ethnic group & & & & \\
\hline Bamilékés & 50 & 96,2 & 14 & 100 \\
\hline Banso & 2 & 3,8 & 0 & 0 \\
\hline Total & 52 & 100 & 14 & 100 \\
\hline $\begin{array}{l}\text { Average number of } \\
\text { children under charge } \\
\text { Level of education }(\%)\end{array}$ & & $6,2 \pm 2,8$ & & $6,57 \pm 2,6$ \\
\hline Primary & 15 & 28,8 & 2 & 14,3 \\
\hline Secondary & 26 & 50 & 8 & 57,1 \\
\hline University & 11 & 21,2 & 4 & 28,6 \\
\hline Total & 52 & 100 & 14 & 100 \\
\hline
\end{tabular}

In Dschang and its surroundings, $57.8 \%$ of the men and $46.2 \%$ of the women surveyed raised broilers. These breeders have an average age of $42 \pm 10.7$ years with a minimum of 18 years and a maximum of 75 years. Laying hen producers comprised $64.3 \%$ of men and $35.7 \%$ of women with an average age of $46 \pm 10.98$ years, a minimum of 30 years and a maximum of 55 years. This result is close to those of [36] on the characteristics of layers producers in the Mifi Division in West Cameroon. However, in Chad, the poultry farmers in the six savanna territories are mainly men $(90 \%)$, with an average age of 36 years, with households having an average of 7 individuals, with 4 of them active. It is mainly farmers (89\%) who have been engaged in poultry farming for an average of 11 years [3]. In Bangui, $82 \%$ of the breeders are men between the ages of 25 and 50 years [43]. In terms of education, all the breeders surveyed have been to school. Breeders with secondary education respectively account for 50 and $57.1 \%$ for broiler and laying hen breeders. Moreover, most of them $(73 \%)$ are under 50 years of age. These characteristics are assets in the perspective of the adoption of modern production techniques and the acquisition of new know-how. The education of breeders is an advantage in the sense that it enables them to be receptive to possible innovations made in the sector and to have the capacity to assimilate the technical know-how necessary for production (formulation of feed, prophylactic programs, hygiene measures, etc.). This situation seems to be much better than in other Central African countries. In Chad, $67 \%$ of poultry farmers have been to school, with $47 \%$ having completed primary school and only $17 \%$ have been to secondary school [30]. In Ouagadougou, about $67 \%$ of the agricultural population has never been to school and $40 \%$ among the rearers [17]. On the matrimonial level, 45 of the surveyed broiler breeders are married and 39 of them are in monogamous regimes. The five surveyed layer breeders are married and are all monogamous. This high proportion of monogamy is comparable to the $74 \%$ reported by [28] but very different from the results of [36], who reported $65.8 \%$ for polygamous homes. However, given the urban context, this situation could be explained by urban habits oriented towards monogamy and the fact that the cost of living is becoming higher, therefore the need to limit family burdens. The average number of dependent children is 06 . This number implies the need for substantial means to support family burdens. As an income-generating activity, livestock farming is of great economic importance for households as a strategy for mobilizing financial resources. In addition, such numbers are generally an important family labor force for livestock farms. In terms of ethnic group of the breeders, Bamilekés are the most represented, with $96.2 \%$ and $100 \%$ respectively for broiler and layer breeders.

The surveyed breeders have an average of 7 years of professional experience and $46 \%$ have less than 5 years experience. In addition, only $17.3 \%$ of broilers and $7.1 \%$ of layer hen farmers reported having received basic poultry training. In addition, less than $5 \%$ of the livestock farmers have already received support from public livestock services. Poultry farming is thus an old activity for many of them. Breeding techniques seem to have been acquired over time through practice. With the economic crisis of the mid-1980s in Cameroon, as well as the decline in coffee and cocoa farming, which was the basis of the economy of the West Region of Cameroon, thus poultry farming quickly emerged as a profitable alternative especially in view of the availability of maize in this region, which constitutes $60-70 \%$ of the poultry feed [19], [20].

Table 2. Some feed formulas used by the surveyed breeders.

\begin{tabular}{|c|c|c|c|c|}
\hline \multirow[b]{2}{*}{ Simple feed } & \multicolumn{2}{|c|}{ With $5 \%$ concentrate } & \multicolumn{2}{|c|}{ With $10 \%$ concentrate } \\
\hline & $\begin{array}{l}\text { Formula } \\
1 \text { (Kg) }\end{array}$ & $\begin{array}{l}\text { Formula } \\
2(\mathrm{Kg})\end{array}$ & $\begin{array}{l}\text { Formula } 1 \\
(\mathrm{Kg})\end{array}$ & $\begin{array}{l}\text { Formula } \\
2(\mathrm{Kg})\end{array}$ \\
\hline Corn & 65 & 65 & 56 & 65 \\
\hline Soybeans & - & - & 34 & - \\
\hline Soybean meal & 18 & 15 & - & 15 \\
\hline Cottonseed cake & 10 & 10 & - & 10 \\
\hline Kernel cake & - & 3 & - & - \\
\hline Concentrate & 5 & 5 & 10 & 10 \\
\hline Bone meal & 2 & 2 & - & - \\
\hline Cooking salt & - & - & 0,125 & - \\
\hline Total & 100 & 100 & 100,125 & 100 \\
\hline
\end{tabular}

Moreover, poultry farming is part of the culture of the region and the production techniques are known to several 
breeders surveyed. In the savannah zones of Africa, if the traditional breeding was mainly intended for selfconsumption, rituals or to weave social bonds, today the activity is strongly monetarized. In Northern Cameroon, this activity is often carried out by women and plays an important role in food, income generation and savings for most modest families [36].

On the other hand, most of the breeders surveyed have not received basic training in animal husbandry, which could obviously be seen as a handicap in mastering the production techniques necessary for the success of a poultry farm. However, successful breeding of broiler chickens and laying hens require know-how that can be acquired on the job, by training courses or by reading breeding documents. It can be assumed that the time spent in poultry farming ( 5 years and more) and therefore the considerable experience gained constitutes an opportunity for these breeders to learn the farming techniques, but it would be important to constantly do technical follow-ups to rectify certain bad practices if they exist. The surveyed breeders however have professional experience, $46 \%$ have less than 5 years of experience. $64.3 \%$ of layer breeders are engaged in livestock production as their main activity, which could be justified by the fact that this activity requires greater investment in capital and monitoring and a large number of livestock to be profitable. $50.0 \%$ of broiler breeders do this as a secondary activity. This is probably due to the fact that it is a short-term activity (short production and sales cycle), requiring relatively low investment and monitoring, and feasible with limited labor. Also, several chicken breeders do not do so on a permanent basis throughout the year, but generally conduct production bands at certain times to target specific moments of high demand such as festive periods. $41 \%$ of chicken breeders and $64.3 \%$ of layer breeders practice agriculture as a secondary activity. This number of farmers is low compared to that reported by [30]. It can be argued that in urban and periurban areas, the availability of land for agriculture is not important in view of the very rapid growth of the population and the rapid advance of the urban front. Land is much more valued in real estate.

The surveyed breeders are also civil servants, private sector workers, farmers, students and traders. Among them, $25 \%$ of broiler breeders are "provendiers" (manufacturers and sellers of poultry feed), compared with $28.5 \%$ for layer breeders. The objectives underlying this multi-activity seem to be the desire to increase and consolidate incomes through a diversification of income-generating activities. For some, breeding is practiced while waiting to find another complementary or more stable activity. This is also the case in Brazzaville in the Republic of Congo where urban and peri-urban livestock farming is practiced by different social and occupational classes, but mainly by households with a low living standard, having a poverty profile and having previously practiced this activity [4]. The majority (96.2\%) of the surveyed broiler and layer producers do not belong to a producer organization. This could constitute a handicap for activities requiring a collective dynamism.
$86.5 \%$ of the broiler breeders own the livestock building, while $13.5 \%$ lease their livestock building. $92.9 \%$ of the laying breeders are owners of the livestock building, while $7.1 \%$ are rented. $96.1 \%$ of broiler breeders and $100 \%$ of layer breeders live in electrified brick houses (built with permanent materials). $55.8 \%$ of broiler breeders and $57.1 \%$ of layer breeders have a car as a means of transport. $88.5 \%$ of broiler breeders and $100 \%$ of layer producers declared that they were motivated by the search of profits. On the other hand, there are some who practice this breeding by imitation or for various reasons such as: the availability of poultry feed (in the case of several poultry feed vendors), the passion for breeding, the knowledge in breeding, and the search for droppings for agriculture. Chicken dejections, called chicken droppings, are much sought after in urban market gardening, and there is a great demand from a portion of the populations that use them as organic fertilizer in agriculture. A $100 \mathrm{~kg}$ bag of layer droppings costs 1000-1500 FCFA / bag, while the same bag of broiler droppings costs between 500-800 FCFA in Yaoundé [41]. This price of dung is high compared to other regions of Sub-Saharan Africa, for example in Senegal a $50 \mathrm{~kg}$ bag of layer droppings costs 600 FCFA [33]. $78.8 \%$ of chicken breeders and $42.9 \%$ of layer farmers use their livestock droppings for agriculture themselves. This is also common in other regions of Cameroon and even in Africa, for example in Brazzaville one of the main motivations for the practice of livestock farming in the city is the search for droppings. In fact, the results show that about $42 \%$ of the people exclusively involved in livestock farming or combining livestock with crops use manure, mainly for house gardening (94\%), sales (4\%) and barter that is, manure for vegetables $(1.4 \%)$ [4].

In all the production areas studied, $86.5 \%$ of the workforce is still family-owned for broiler breeders and mixed for layer producers, of whom $71.4 \%$ use paid labor (1000F CFA / day $\approx 1.52 €$ ) and $28.6 \%$ the unpaid family hand. The bulk of livestock financing is by credit, with an annual interest rate of about $12 \%$ and a repayment schedule of 6 months to one year. $57.7 \%$ of broiler breeders and $64.1 \%$ of layer breeders use credit, while $30.8 \%$ of chicken breeders and $21.1 \%$ of layer breeders use personal savings.

Table 3. Different sources of financing for the studied farms.

\begin{tabular}{lllll}
\hline Finance source & \multicolumn{2}{l}{ Broiler breeders } & \multicolumn{2}{l}{ Layer breeders } \\
\hline & $\mathbf{N}$ & $\mathbf{\%}$ & $\mathbf{N}$ & $\mathbf{\%}$ \\
\hline Personal fonds & 16 & 30,8 & 3 & 21,4 \\
Credit & 30 & 57,7 & 9 & 64,3 \\
Family & 6 & 11,5 & 2 & 14,3 \\
Total & 52 & 100 & 14 & 100 \\
Sources of credit & & & & \\
Tontine & 16 & 30,8 & 4 & 28,5 \\
Familial & 3 & 5,8 & 2 & 14,3 \\
Banks & 3 & 5,8 & 3 & 21,4 \\
Micro-finance & 8 & 15,4 & 5 & 35,7 \\
None & 22 & 42,3 & 0 & 0 \\
Total & 52 & 100 & 14 & 100 \\
\hline
\end{tabular}

The main credit financing structures to the surveyed breeders are: "Crédit Communautaire d'Afrique" and 
"Afriland First Bank". However, family aid/support is also an important source of funding, especially in the Western Region where solidarity associations are commonplace and of paramount importance. In fact, $11.5 \%$ of chicken and $14.3 \%$ of layer breeders began their activities with financial and or material support of family members. The different sources of finance of the studied farms are listed in Table 3.

\subsection{Spatial Distribution of Broiler Chicken and Layer Farms in the Dschang Area}

Livestock distribution maps can be used for epidemiological modeling, livestock manure management, biosecurity, food safety and environmental impact assessment [26]. Thus, in order to better appreciate this distribution, the farms were represented by distinguishing the two types studied and taking into account the average number of subjects raised per band (Figure 1). It was found that there are more livestock farms on the outskirts of the city than in the city center. The spatial distribution of livestock in the study area has many similarities with other parts of Central and West Africa, particularly in Central African Republic [29] and Chad [31]. This distribution can be explained by the unavailability of land to shelter the poultry houses and the risks of olfactory nuisance. [44] point out that urban livestock farming is often associated with environmental degradation, mainly because of waste. In addition, urban farmers have enormous facilities for food and veterinary products supply compared to farmers in the rural areas. The higher number of broiler farming in urban and peri-urban areas is probably due to the fact that it is cheaper in terms of investment and the return on investment is also short-lived compared to laying hens. It should also be noted that large metropolitan areas such as Douala and Yaoundé, as well as the neighboring countries of Cameroon such as Gabon, Congo and Equatorial Guinea, get their supplies from the Western Region, thus increasing the demand in poultry products. According to [42], poultry farming activity is generally constrained by food availability, road access, temperature, aridity, access to water, human activities, access to inputs and major markets. These limitations influence the spatial distribution of livestock rearing. According to the same authors, the analysis of maps produced in Morocco highlights the most concentrated and productive areas in poultry farming. It also shows the concentration of poultry farming on the axis linking Settat to Casablanca, in the vicinity of the industrial zones with slaughterhouses and to the adjacent strip of Casablanca and Rabat, with a predominance of chicken. These authors also believe that this distribution can be explained by natural, economic, geographical, demographic and logistic factors characterizing the region under study. Livestock numbers vary at different levels during the year. This variation is generally made by the farmer to adapt to fluctuations in the demand for poultry products between dry and rainy seasons, as [6] also observed in the Cape region of Senegal. $48.1 \%$ of broiler breeders are located in urban areas and have a livestock size of between 50 and 350 animals per breeding band. The layer farmers all use the buildings that were originally intended for rearing.

\subsection{Technical Characteristics of the Studied Farms}

$96.2 \%$ of the breeders surveyed do not seek to know the strain they raise especially the broiler farmers. This is abnormal for the competitiveness of the poultry sector in the area. This seems to be justified by ignorance of the importance of the race on one hand and, on the other hand, by the lack of basic training in breeding. They are often interested in the society that delivers the chicks and the provender. However, in order to maximize profit, a single company can deliver several strains that may not have the same zootechnical performance in the area. In addition, $78.6 \%$ of layer producers know their strain and often prefer to buy their supplies outside the country because they believe that foreign suppliers do a good job of sorting out better subjects. Chicks are either produced from hatching eggs imported from European or Latin American countries or produced in Cameroon. There are about 14 farms in the towns of Bafoussam, Douala and Yaoundé that raise parental strains and therefore use hatched eggs from their own livestock to feed their hatcheries. The strains raised in the area are: Lohman Brown, Hy Line Red, Isa Brown, and Shaver for laying. Broiler strains are those with a fastgrowing rate (Cobb 500 and Hubbard).

Table 4. Level of knowledge of the strain/breed raised by breeders.

\begin{tabular}{lllll}
\hline Knowledge of the & \multicolumn{2}{l}{ Chicken breeders } & \multicolumn{2}{l}{ Layer breeders } \\
\cline { 2 - 5 } variety breed & $\mathbf{N}$ & $\mathbf{\%}$ & $\mathbf{N}$ & $\%$ \\
\hline No & 50 & 96,2 & 3 & 21,4 \\
Yes & 2 & 3,8 & 11 & 78,6 \\
Total & 52 & 100 & 14 & 100 \\
Variety & & & & \\
Broilers & & & & \\
Cobb & 1 & 50 & & - \\
Hubbard & 1 & 50 & & - \\
Total & 2 & 100 & & \\
Layers & & & & 42,9 \\
Lohman Brown & - & - & 6 & 14,3 \\
Shaver & - & - & 2 & 14,3 \\
Hy Line & - & - & 2 & 7,1 \\
Isa Brown & - & - & 1 & 100 \\
Total & - & - & 11 & \\
\hline
\end{tabular}

According to [11], the Cobb 500 consumption index varies from 1.42 to 4.8 in the warm season and from 1.19 to 5.79 in the cold season in Senegal. 84, 6\% of broiler breeders have not been trained, compared to $15.4 \%$ who have been trained. Of those trained, $25 \%$ report having been trained on a poultry farm, $50 \%$ at a training school, and $25 \%$ at training seminars. For layer breeders, $21.4 \%$ report having received training while $78.6 \%$ have not received training. All those who have received training declare that they received it in a training school. In Niger, apart from 2 or 3 livestock managers, poultry farmers have generally not had any training in poultry farming when they embarked on the trade [2]. Most of the surveyed broiler breeders (82.5\%) used dwelling houses as livestock buildings without making any changes. These houses are generally too closed and the ventilation is 
not regulated due to lack of ventilation systems. This also corroborates the results of [6] in the urban area of Cape Verde in Senegal. Moreover, the buildings are not generally oriented perpendicular to the prevailing winds as recommended by [32]. In general, excessive sunlight can lead to picking and cannibalism. Layer chicken farmers use buildings that are better suited to broiler breeders. In Bangui, in the semi-industrial system, $89 \%$ of chicken breeders have poultry houses and $42 \%$ have received training (Keita 1999). Table 5 shows the distribution of breeders according to the method of acquisition and construction of livestock buildings.

Table 5. Distribution of breeders according to the method of acquisition and construction of buildings.

\begin{tabular}{lllll}
\hline Method of building acquisition & \multicolumn{2}{c}{ Broiler breeders } & \multicolumn{2}{c}{ Layer breeders } \\
\hline Rent & 7 & 13,5 & 13 & 92,9 \\
Owner & 45 & 86,5 & 1 & 7,1 \\
Total & 52 & 100 & 14 & 100 \\
\hline
\end{tabular}

\begin{tabular}{lllll}
\hline Method of building acquisition & \multicolumn{2}{l}{ Broiler breeders } & Layer breeders \\
\hline $\begin{array}{l}\text { Construction mode } \\
\text { Half wall + wire mesh or }\end{array}$ & 10 & 19,2 & 10 & 71,4 \\
bamboo & 33 & 63,5 & 2 & 14,3 \\
Closed walls & 6 & 11,5 & 2 & 14,3 \\
Exclusively with bamboo & 3 & 5,8 & 0 & 0 \\
With plank-boards & 52 & 100 & 14 & 100 \\
Total & & & & \\
\hline
\end{tabular}

Most of the surveyed broiler breeders use linear feeders made of wood ranging in length from 60 to $150 \mathrm{~cm}$ and circular fillers with manual filling and capacities ranging between 2.5 and 10 liters. $1.4 \%$ of layer breeders use linear wooden feeders and circular manual filling watering troughs between 5 and 10 liters, while $28.6 \%$ use plastic feeders and circular watering troughs with automatic filling. Indeed, automatic filling drinkers cost more and also require an additional investment, in particular a pump and water distribution device, and an appropriate handling technique.

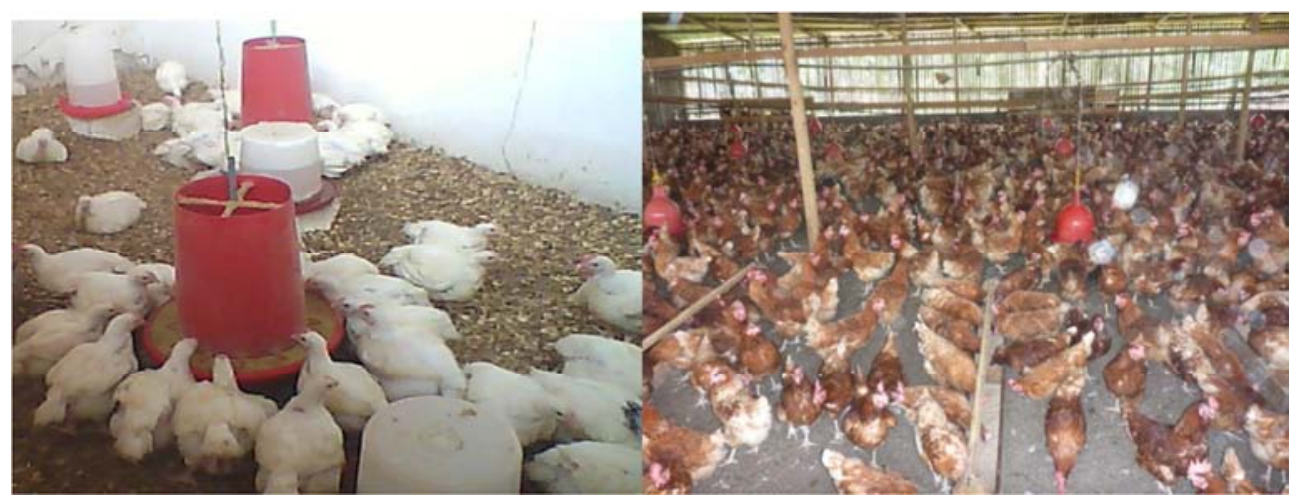

Figure 2. Chicken coop equipped with manual linear feeders and automatic drinkers (right), and manual feeders and drinkers (left).

The price of day-old chicks produced in hatcheries in the country varies from one period of the year to another. It is higher 3 months before the end of the year. The purchase price of chick varies from 450 to $550 \mathrm{~F}$ CFA for broiler chicks and 650 to 775 F CFA for the future laying chicks at the beginning of the year and before the end year feasts respectively. The duration of broiler breeding in the Dschang area varies according to the breeders' technicalities and the seasons. $50 \%$ of the surveyed farmers sell chickens when they have at least $2 \mathrm{~kg}$ live-weight at the age of 45 days, but they sometimes keep chickens for up to 60 days during periods of low demand and production difficulties. Breeding of chicks is difficult and requires good technical skill. $44.30 \%$ of respondents prefer to buy 21-day-old chicks which they raise for up to 60 days before bringing them to the market at a slightly higher price (4000 to 5000 CFAF per head). The duration of layer breeding ranges from one day to a maximum of 23 months. In Bangui, according to production know-how, the average length of broiler breeding is 56 to 60 days [43] and [29] and 50 to 60 days in Niamey [2]. The duration of laying hens ranges from 1 day to 23 months at most and is also 1 to 23 months in Bangui (Kando 1995 and [4].

As sources of energy for heating, $80.8 \%$ use electricity for broiler breeding, $15.4 \%$ use wood, generally eucalyptus and $3.8 \%$ use charcoal. For the breeding of laying hens, 50\% use eucalyptus wood because the heating time is longer, which makes it possible to compensate for untimely cuts in electrical energy. $42.9 \%$ of laying hen producers uses electricity and $7.1 \%$ use charcoal.

The egg-laying age varies between 5.5 and 6.5 months with an average of 6 months and laying rates range between 80 and $90 \%$ with an average of $82.5 \%$. The rate of spawning at the peak varies between 80 and $90 \%$ with an average of $85 \%$ at an average age of 12 weeks after the onset of laying. This would be linked to the management conditions of the subjects, in particular the standards of the environment, food, hygiene and housing and even the strain used. In the Central African Republic, particularly in Bangui, the mortality rate is $13 \%$. In laying hens, the age and live weight at the start of laying are 5 months and $1.5 \mathrm{~kg}$. The egg-laying period is 15 to 18 months, with an annual average of 145 eggs with an average weight of $55 \mathrm{~g}$, a breaking rate of $4.4 \%$, and a mortality rate of $18 \%$ [43]. [1] observed $95 \%$ spawning peaks and average laying rates for the entire period of laying production varied between $52 \%$ and $79 \%$. The dates of egg production vary from one farmer to another, which is linked to the technical nature of the breeders and to the respect of 
the standards of breeding. The majority of surveyed breeders regularly follow the planned sanitary protection program which consists of disinfection of the poultry house with a disinfectant consisting of quicklime, cresyl and bleach before the subjects are introduced into the building, vaccination against diseases such as infectious bronchitis, Newcastle disease and gumboro disease, deworming (Levamisole, vetacox, anticox and sulfacox) and administration of vitamins (Super Multivit, Amin 'Total) and antibiotics (Ciplofloxacin, Doxycycline, Gentamycin, Oxytetracycline (Limoxin) Gentadox) for diseases such as coccidiosis and respiratory diseases.

Table 6. Symptoms and health care of some of the diseases encountered.

\begin{tabular}{|c|c|c|c|}
\hline Disease & Clinical signs (diagnosis) & Differential diagnosis & \\
\hline $\begin{array}{l}\text { Gumboro (Subacute, } \\
\text { acute and chronic) }\end{array}$ & $\begin{array}{l}\text { Whitish diarrhea, decreased consumption, } \\
\text { chicks group in tufts, drowsiness, dead } \\
\text { chicks with beak in litter. }\end{array}$ & $\begin{array}{l}\text { Consists of Colibacillosis and } \\
\text { Salmonellosis; Autopsy: blood spots on } \\
\text { the muscles of the wings and thighs. }\end{array}$ & $\begin{array}{l}\text { Symptomatic: antibiotic } \\
\text { Ciplofloxacin (Ciplox) + vitamins }\end{array}$ \\
\hline $\begin{array}{l}\text { Chronic respiratory } \\
\text { disease }(\mathrm{CRD})\end{array}$ & $\begin{array}{l}\text { Cough, breathing difficulties, wheezing, } \\
\text { open mouth, Nasal discharge }\end{array}$ & $\begin{array}{l}\text { Autopsy: black spotted lung, respiratory } \\
\text { tract covered with mucus }\end{array}$ & $\begin{array}{l}\text { Antibiotics of the cyclin family: } \\
\text { Limoxin, Doxycycline, etc. }\end{array}$ \\
\hline $\begin{array}{l}\text { Coccidiosis } \\
\text { and caecal) }\end{array}$ & $\begin{array}{l}\text { Diarrhea a little brown, foaming, decrease } \\
\text { in food consumption, bloody diarrhea for } \\
\text { the chronic case. }\end{array}$ & $\begin{array}{l}\text { Autopsy: hard coagulated blood, blackish } \\
\text { in the intestine or in the caecom as the } \\
\text { case may be, wall of the red organ. }\end{array}$ & $\begin{array}{l}\text { Anticoccidians: vetacox, anticox, } \\
\text { sulfacox, etc. }\end{array}$ \\
\hline
\end{tabular}

In addition, all breeders report having a few disease problems such as salmonellosis, which they claim is due to white diarrhea and Newcastle disease, which is manifested by torticollis. This seems to be partly due to failures to comply with the vaccination program, building standards for the livestock buildings and hygiene conditions. Only $40.4 \%$ of broiler breeders receive assistance from the veterinary service when needed, compared with $85.7 \%$ of layer breeders, and the rest prefer to diagnose and administer care themselves because they cannot cover the costs associated to veterinary services.

The main diseases encountered are coccidiosis according to $69.2 \%$ and $50.0 \%$, and salmonellosis according to $17.3 \%$ and $21.4 \%$ respectively by broiler and layer breeders. It was also found that $14.3 \%$ of layer farmers faced the Gumboro disease, which usually begins during the third week according to the surveys. All the other broiler breeders are not aware of this last disease. Factors favoring disease predominance and epidemics include poor access to veterinary services and doctors, and the absence or poor condition of poultry houses. Table 7 lists the main diseases frequently encountered in the surveyed farms.

Table 7. Main diseases frequently encountered in surveyed farms.

\begin{tabular}{lllll}
\hline \multirow{2}{*}{ Frequent diseases } & \multicolumn{2}{l}{ Broiler breeders } & \multicolumn{2}{l}{ Layer breeders } \\
\cline { 2 - 5 } & $\mathbf{N}$ & $\mathbf{N}$ & \\
\hline Coccidiosis & 36 & 69,2 & 7 & 50,0 \\
Salmonellosis & 9 & 17,3 & 3 & 21,4 \\
Infectious bronchitis & 5 & 9,6 & 2 & 14,3 \\
Gumboro & 0 & 0 & 2 & 14,3 \\
New Castle Disease & 2 & 3,8 & 0 & 0 \\
Total & 52 & 100,0 & 14 & 100,0 \\
\hline
\end{tabular}

Broiler breeders do not often see this disease because the production cycle is relatively short. Many diseases hinder the development of poultry farms in Central Africa. But the Newcastle disease is the major health problem of village family farms.

In the case of by-products like droppings, there is a strong demand from the populations that use them as organic fertilizer in agriculture. Contrary to the price of 1000 to 1500
FCFA / bag for $100 \mathrm{~kg}$ of layer droppings reported by [41] in the urban and peri-urban zone of Yaoundé, in Dschang the laying droppings are sold at the price of 2000 FCFA per bag of $50 \mathrm{~kg}$. Because of the very short production cycle in broilers, their droppings are not of good quality and therefore are not solicited by farmers. The surveys show that $78.8 \%$ of broiler and $42.9 \%$ of layer breeders personally use their livestock manure for agriculture.

\subsection{Constraints to Poultry Production in the Urban and Peri-urban Areas of Dschang}

The poultry sector in the study area faces technical, financial and health constraints. $60 \%$ of the problems mentioned are related to insufficiency in capital, food and animal material. Difficulties in marketing, theft, loss of animals, and the absence of appropriate technical support structures are the second most common problems.

\subsubsection{Technical Constraints}

The poultry building is well designed for $30 \%$ of the breeders visited. For the majority of breeders $(70 \%)$, the chicken coop is rudimentary. Indeed, many failures are raised especially as far as aeration is concerned (totally closed walls) and protection against violent rains in the case of overflowing or inefficient roofing. The lack of monitoring and technical support of producers by zootechnical public health services in the area in terms of animal health, problems of input distribution, dissemination of technology and marketing are also obstacles. The insufficiency or lack of coordination between the services involved and the lack of operational means to ensure their responsibilities in monitoring and follow up of producers, stem from a lack of adequate physical/material and functional organization of the production system [10]. Health monitoring by veterinary officers and livestock technicians is very low in the study area because of financial and logistical requirements by the technicians and the lack of organization of the farmers. These constraints are the same as those reported in intensive pig farming [22] and poultry [28] both in Cameroon and Central African Republic. 


\subsubsection{Financial Constraints}

The breeding of broilers as well as that of layers are not accessible to all strata of the population. Indeed, this breeding requires considerable financial resources. In general, chicks, medicines and over $50 \%$ of maize for food production are imported inputs [27]; [36]. In Cameroon, the cost of producing a chicken is very high, about 1540 FCFA, i.e. almost 2.5 Euros [37]. This cost of production increases over time, according to the same author, it varies between 1750 and 2000 FCFA for broilers and between 38 and 45 FCFA per egg according to the type of farms and the performance of the farmers. The day-old broiler chick costs between 450 and 550 FCFA and the future layer chick between 650 and 775 FCFA. Whereas in Senegal, for example, the price of a broiler chick is 460 FCFA and that of the future laying chicks is 550 FCFA [33]. Breeders are not masters of the supply period, with the importers preferring to group demands to make larger orders.

The surveyed producers find it very difficult to obtain finance for the purchase of poultry equipment such as feeders and drinking troughs. These difficulties are the same as those reported by [39] in the broiler chicken industry in Senegal. The poor organization of the market and the lack of a chain of slaughter and cold houses to condition and conserve the unsold chickens signify that many poultry farmers are limited to punctual operations aimed at consumer demand linked to religious and customary origins or family festivities. Indeed, because of the numerous losses recorded in this activity the banks are not very favorable to finance livestock in general and the poultry sectors in particular. The few cases of finance by microfinance institutions that exist concern only $6.6 \%$ of layer farmers and are not adapted to the activity: either the interest rate is too high (2.5\% per Month) as is the case for $57 \%$ of breeders; or the deferral is too short compared to the activity (which is the case for $21.2 \%$ of breeders), especially in the breeding of laying hens. The amounts allocated are for the purchase of chicks and food only, while the construction of the buildings and the purchase of livestock equipment are not financed. There is a need for appropriate credit mechanisms, which finance both the construction of buildings and the purchase of livestock equipment. According to [34], if the investment (building and livestock equipment) is not properly assured, one cannot expect profitability. In addition to the high costs (450 to 550 FCFA for broilers and 650 to 775 FCFA for layer chicks), farmers are often not supplied on time because the country's hatchers fail to cover/satisfy local demand which increases every day. Livestock, and especially poultry, is a "high risk" area for financial institutions. Under these conditions some institutions refuse to finance poultry farming. Indeed, in field surveys, the majority of breeders do not have a consistent guarantee (land title, movable or immovable property) to secure credit in a bank or a microfinance institution.

\subsubsection{Food Constraints}

Food plays a major role in commercial poultry farming, where it accounts for more than $2 / 3$ of production costs and the main limiting factor [24]; [27]. The constraints inherent to food production were summarized by [28] in a survey of some manufacturers. From that study, as in the present study, it appears that among the explanatory elements, the lack of technicality/know-how of certain promoters seem to be preponderant. The nutritional quality of artisanal feed on some unqualified poultry farms, irregular and insufficient distribution of food, and the prolonged rupture of food-stocks on farms do not promote optimum production of these farms. In addition to these difficulties, the high price of raw materials (150 to $250 \mathrm{FCFA} / \mathrm{kg}$ of maize and 400 to 500 FCFA / $\mathrm{kg}$ of soybeans in the same year), the high cost of amino acids (3000 and 5000 FCFA / $\mathrm{kg}$ for methionine and lysine respectively) and imported premixes. Also, the maize and fish used are often of poor quality during the rainy season. Raw materials are rarely analyzed. The subequipment in modern formulation tools is notorious and does not allow the integration of the variation of raw material prices in feed formulation.

\subsubsection{Health Constraints}

In the field of animal health, livestock farms are generally well monitored for some and poorly monitored for others. Almost all (100\%) of the breeder's state that they must comply with the minimal preventive measures and hygiene standards (cleaning, disinfection and sanitary gaps) necessary for the prevention of major poultry diseases such as salmonellosis, infectious bronchitis and Newcastle disease. Moreover, the majority of care provided is based on the use of antibiotics (doxicycline, amoxicycline, etc.) and dewormers by the breeders themselves. [30] and [28] respectively reported the same sanitary constraints in similar studies in Chad and Cameroon. The most frequent disease encountered in the surveyed farms is coccidiosis with $69.2 \%$ for broiler and $50 \%$ for layer farms. However, most of the care provided is based on veterinary, antibiotic and deworming products. Problems of dosage and effectiveness are sometimes observed by breeders. Sanitary constraints are represented by risk factors in the poultry houses. These risk factors are numerous (hygiene, water quality, temperature, and humidity) and can act in synergy or individually. The success of any breeding depends on the means put in place to eliminate or at least reduce the most possible constraints to its development. But to this must be added the socioeconomic and political environment which, through stability, plays a crucial role in the farmers' willingness to increase production and thus income [22].

\subsubsection{Marketing Constraints}

All broiler traders note the instability of urban and periurban market as their first obstacle. This market instability results from price fluctuations and chicken shortages. Then there are financial problems $(93.33 \%)$, insufficient water $(86.66 \%)$, diseases $(80 \%)$, mortality $(53.33 \%)$, insalubrious markets (33\%) and the risk of aggression and imprisonment $(33.33 \%)$. Assaults usually occur when traveling in periurban areas to obtain chickens. These aggressors are recruited among the transporters (drivers of motorcycle) who 
accompany the traders during these displacements. The risks of imprisonment are due to the fact that some thieves present themselves as producers and sell stolen chickens on farms to traders who become receivers without knowing it. Lack of market information is also a significant constraint. The laying hen producers do not have these problems since they deliver their eggs to customers to whom they have already established sales contracts in the cities of Douala, Yaoundé and even in Chad. In Dschang, the price of a life chicken with an average weight of $2 \mathrm{~kg}$, ranges from 2,500 FCFA and 2,800 FCFA / subject with peaks of 3,000 FCFA during the holidays. This price is very fluctuating given that the companies that supply the chicks are also producers of broilers, thus have the ability to influence the prices in the market. In Central African Republic, the price varies between 3,000 and 3,500 CFA francs [29].

\section{Conclusion}

This study shows that poultry production in Dschang presents some prospects for development due to the fact that Dschang has become a university town in recent years. The number of subjects and the number of breeders are higher in the peri-urban zone than in the urban area. This activity is predominantly carried out by $57.8 \%$ and $64.3 \%$ of men respectively for the breeding of broilers and that of laying hens. Livestock numbers range from 500 to 1,500 for broiler chickens and from 750 to 1,000 layers for livestock farmers in urban areas with a higher livestock population in the periurban area of around 4,000 to 10,000 broilers compared with 2000 to 5000 layers. Unpaid family labor is predominant with $86.5 \%$ for broiler breeding. However, for laying hens, paid labor represents $71.4 \%$ (1000 CFA francs / day). The performance of this breeding, already appreciable, can still be substantially improved by eradicating the main constraints it faces: zootechnical, food, health, commercial and technical supervision constraints. The main problems are: failure to comply with technical standards of poultry buildings, lack of financial resources, the absence of financial structures adapted to the activity, non-organization of farmers and almost lack of monitoring from technical services.

It is clear that, if these essential conditions are fulfilled, poultry farming in the area would in the short term provide real possibilities for increasing the national supply of animal protein and improve the living condition of the actors in the poultry sector. Policy-makers should emphasize on better organization of technical support structures, as they must have the means to carry out their tasks. Attention should also be paid to the increase in zootechnical and veterinary technicians and in the training and retraining of breeders. In addition, an incentive environment must be created to promote appropriate financing structures as well as the infrastructure for the slaughter and conservation of broilers. The State must also ensure that the quality of inputs (chicks, food, veterinary products, etc.) is monitored. Particular emphasis should also be placed on strengthening the production of maize, which is an essential component of poultry feed.

\section{References}

[1] A. G. Zoffoun, J. F. Almeida and F. Demoulin "Manuel D'aviculture à L'usage des Pisciculteurs pour les Élevages Associés" Pamr-Mono, P. 57, 2001.

[2] A. Idi, O. Ganda Idé, "Revue du Secteur Avicole" Fao, 69p. 2009.

[3] A. Maho, N. Ndeledje Gondje, L. Y. Mopate, and K. Ganda "La Maladie de Newcastle au Sud du Tchad: Périodes de Pic Épidémique et Impact de la Vaccination" Rev. Sci. Tech. Off. Int. Epiz., 23 (3): 777-782, 2004.

[4] A. Mfoukou-Ntsakala, M. Bitémo, N. Speybroeck, G. Van Huylenbroeck, and E. Thys, "Agriculture Urbaine et Subsistance des Ménages dans une Zone de Post-Conflit en Afrique Centrale" Biotechnol. Agron. Soc. Environ., Volume $10 \quad$ (Numéro 3: 237-249 http://Popups.Ulg.Ac.Be/Base/Document.Php?Id=108, 2006.

[5] Acdic (Association Citoyenne de Défense des Intérêts Collectifs) "L'importation Massive de Poulet Congelé au Cameroun: État des Lieux, Enjeux et Alternatives". Rapport D'études, 168 P, 2005.

[6] B. Arbelot, H. Foucher, J. F. Dayon, and A. Missohou "Typologie des Aviculteurs dans la Zone du Cap-Vert au Sénégal. Revue Élev. Méd. Vét. Pays Trop., 50 (1), 1997.

[7] B. Lecrerq "Possibilités D'obtention et Intérêt des Génotypes Maigres en Aviculture. Inra, Prod. Anim., 2 (4): 275-286p, 1990.

[8] Bucrep (Bureau Central de Recensement et d'Etude de la Population au Cameroun) Troisième Recensement Général De La Population Et De L'habitat; Rapport De Présentation Des Résultats Définitifs, Yaoundé, Cameroun, 65p, 2010.

[9] C. Awono Bessa, C. Laroche-Dupraz, J. F. Grongnet, D. Vermersch, M. Havard, and A. Lhuissier "Déterminants de la Consommation Urbaine de Poulet de Chair au Cameroun. Cas de la Ville de Yaoundé" In Agricultures et Développement Urbain en Afrique Subsaharienne (Parrot L., Coordinateur). Tome 1: Gouvernance et Approvisionnement des Villes. Edition L'harmattan, P. 209-218, 2005.

[10] C. Barrier, J. M. Bellot, J. Sarniguet and P. Thomas "La Relance du Secteur Élevage dans les Pays de la Zone Franc Après la Dévaluation" Ministère de la Coopération, Caisse Française Dév. Paris, France, 107 P, 1996.

[11] C. L. Adooko Betene, "Evaluation des Performances Zootechniques et Économiques en Période Post Reforme D'élevage de Poulets de Chair (Souches Cobb 500 Et Jupiter) dans la Région de Dakar" Université Cheikh Anta Diop De Dakar - Doctorat D'état en Médecine Vétérinaire, 170p, 2005.

[12] C. Laroche Dupraz, C. Ropars Collet "Disruption on Urban Chicken Markets in Haiti and Cameroon: The Role of SocioEconomic Factors on Chicken's Consumption" 3èmes Journées de Recherches en Sciences Sociales, Inra, Sfer, Cirad 32p, 2009.

[13] C. Ly "Les Enjeux d'une Politique Avicole pour le Sénégal", Communication pour le Séminaire de Lancement du Projet " Développement Intégré de L'aviculture Périurbaine ". Isra/Eismv/Ensa/Fnraa, 31 Octobre 2001, 13p, 2001. 
[14] D. N. Awa, A. M. Tenghe "Poultry Production in the SudanoSahelian Region of North Cameroon: Constraints and Opportunities for Improvement" Paper Presented at The National Forum on Food Security in The Sudano Sahelian Region of Cameroon, Organised by The Cameroon: Academy of Science in Yaounde - Cameroon on June 18, 2008.

[15] D. N. Awa, D. M. Achukwi, E. Niba, T. K. Manchang, A. Wade, A. Asongwed-Awa, and A. L. Dongmo "Animal Health in The Traditional Livestock Systems of North Cameroon: Risk Factors, Health Management and Constraints. Final Report of Diagnostic Survey of Animal Health in Selected Sites" Programme 2.5, Ardesac - Irad, Garoua, Cameroun, 12 P, 2006.

[16] E. B. Sonaiya, S. E. J. Swan "Production en Aviculture Familiale" Manuel FAO de Production et Santé Animales. Un Manuel Technique. Ed. Fao, Rome. Ibs 92-5-205082-5, 136p, 2004.

[17] E. Thys, N. Speybroeck, M. Ouedraogo, S. Geerts "Socio Economic Determinants of Household Livestock Keeping in Semi-Arid Western Africa" J. Arid Environ. 63, P. 475-496, 2005.

[18] F. Misser "Dossier « Transformer L'agriculture Familiale » " Défis Sud Bimestriel D’information Nº 119, 3p, 2014.

[19] G. H. Fongang Fouepe "Cameroun: La Survie Des Paysans Menacée" Revue Pour N 185, Pp. 14-17, 2005.

[20] G. H. Fongang, Fouepe "Les Mutations du Secteur Agricole Bamiléké (Cameroun) Étudiées à Travers ses Acteurs: Une Analyse à Partir des Localités de Fokoué et de Galim. Thèse de Doctorat: Institut Des Sciences et Industries du Vivant et de L'environnement de Paris (AgroParisTech), Département des Sciences Économiques et Sociales, UFR de Sociologie. Paris, France, 2008.

[21] G. Kando "L'agriculture Urbaine en Afrique Tropicale: Revue de Littérature; Résultats de Visites aux Institutions de l'Afrique de L'Ouest et Stratégie D'appui à La Mise en Place D'un Projet de Recherche Régionale Sur L'agriculture Urbaine" Centre De Recherche pour le Développement International, Division de L'environnement et des Ressources Naturelles, 38 Pages, 1995.

[22] G. Ndébi, J. Kamajou and J. Ongla "Analyse des Contraintes au Développement de la Production Porcine au Cameroun" Tropicultura, 27, 2: 70-76, 2009.

[23] H. Ba "Contribution à L'étude de L'influence des Niveaux D'alimentation sur les Performances de Croissance, de L'état D'engraissement et le Bilan D'azote en Fonction de L'âge chez les Poulets de Chair" Th. Med. Vet.: Dakar; 54 P, 1992.

[24] H. S. Chang, "Overview of The World Broiler Industry: Implications for The Philippines" Asian Journal of Agriculture and Development, 4 (2). P 67-82, 2007.

[25] J. Lemouogue "Citadins-Agriculteurs et Mutation des Relations Ville /Campagne dans Le Périmètre Urbain d'une Ville Moyenne: Cas de la Ville de Dschang (Ouest Cameroun)" Thèse de Master, Université de Dschang 157p, 2007.

[26] J. P. Diann, W. Junxi, C. E. Erle, F. Gale, T. P. Van Boeckelf, W. Wint, T. Robinson, X. Xiao, and M. Gilbert "Modelling the Distribution of Chickens, Ducks, and Geese in China" Agriculture, Ecosystems and Environement 141 (381-389), 2011.
[27] J. R. Kana, D. Fon, Engwali, H. Defang Fulefack, A. Teguia, R. Ngouana Tadjong, H. Mube Kuietche, Y. Tefack, and H. R. Zambou "Economics of Broiler Production Fed on Various Dietary Levels of Cassava Flour and Cassava Fiber Supplemented with and Without Palm Oil" Journal of Animal Production Advances, 4 (7): 455-462. Doi: 10.5455/Japa.20140713053805, 2014.

[28] J. Tchoumboué "Les Facteurs limitants du Petit Élevage Intensif de Porc et Volailles au Cameroun" Revue D'elevage et de Médecine Vétérinaire des Pays Tropicaux, 36, 4, 409413, 1983.

[29] Kota-Guinza "Elevage et Industries Animales en République Centrafricaine: État des Lieux, Propositions D'actions Prioritaires" FAO, Division de Production et de la Santé Animale (Aga), 80p, 2007.

[30] L. Y. Mopate, A. Maho "Caractéristiques et Productivité des Élevages Familiaux de Poulets Villageois au Sud du Tchad" Revue Africaine de Santé et de Production Animales (Raspa), Vol. 3 (1): 41-46, 2005.

[31] L. Y. Mopate, O. A. Idriss "Etat de L'aviculture Familiale au Tchad et les Perspectives de son Développement" Etudes et Recherches Sahéliennes, Insah. Bamako, Mali, Vol. 6-7: 7-15, 2002.

[32] M. Czarick, B. D. Fairchild "Poultry Housing for Hot Climates. in Daghir N. J." Poultry Production in Hot Climates, Second Edition. Cab International. P 81-131, 2008.

[33] M. M. Diagne "Analyse de la Compétitivité de la Filière Avicole Semi-Industrielle dans la Zone des Niayes" Mémoire de Fin D'études, Université de Thiès, République du Sénégal, 100p, 2008.

[34] M. Traoré "Evaluation de L'impact d'un Transfert de Paquet Technique (Amélioration Génétique et des Conditions D'élevage) Sur la Génération de Revenus en Aviculture Traditionnelle dans les Niayes" Thèse Méd. Vét.: Dakar; $123 \mathrm{p}, 2005$.

[35] MINEPIA (Ministère de L'Elevage, des Pêches et des Industries Animales) "Schéma Directeur pour le Développement des Filières de L'élevage au Cameroun" Volume Ii: Cartographie Des Filières 82p, 2009.

[36] N. E. Teleu and A. Ngatchou "Première Évaluation du Secteur Avicole au Cameroun: Structure et Importance du Secteur Avicole Commercial et Familial pour une Meilleure Compréhension de l'enjeu de L'influenza Aviaire" Rapport des Consultants Nationaux, FAO, Projet Osro/Glo/Mul [Emergency Assistance for the Control and Prevention of Avian Influenza], Representation FAO, Yaoundé - Cameroun 48p. Http://Www.Fao.Org/Docs/Eims/Upload/213743/Agal_Poultrys ector_Cameroun_May06_Fr, 2006.

[37] N. I. Njikam "Troupeaux et Cultures des Tropiques: Spéculation en Poules Pondeuses et Poulets de Chair au Cameroun: Compte D'exploitation" 92p. 2003.

[38] N. J. Daghir, "Present Status and Future of The Poultry Industry In Hot Regions. In Daghir N. J." Poultry Production in Hot Climates, Second Edition. Cab International. P1-11, 2008.

[39] P. E. Habamenshi, "Contribution à L'étude des Circuits de Commercialisation du Poulet de Chair au Sénégal: Cas de la Région de Dakar" Thèse: Méd. Vét.: Dakar, Sénégal, 120p, 1994. 
[40] P. Gerber, P. Chilonda, G. Franceschini, and H. Menzi "Geographical Determinants and Environmental Implications of Livestock Production Intensification in Asia" Bioresource Technology 96, 263-276, 2005.

[41] P. Nguegang Asaa "L’agriculture Urbaine et Périurbaine à Yaoundé: Analyse Multifonctionnelle d'une Activité Montante en Économie de Survie" Prosper Thèse Ulb 200p, 2008.

[42] R. Aboutayeb, Y. Koulali, A. Madar, and A. Sbia, "Cartographie et Analyse de la Distribution des Elevages Avicoles en utilisant le Système D'information Géographique: cas de la Région Chaouia Ouardigha au Maroc" « Sciences et
Techniques" Agriculture Science Lib Editions Mersenne: Volume 5, $\mathrm{N}^{\circ}$ 130518, 13p, 2011.

[43] S. Keita "Commercialisation des Produits Avicoles à Bangui (Rca): Situation Actuelle et Perspective D'amélioration" Mémoire de Dess Et Master Natura de Productions Animales En Régions Chaudes, 97 P, 1999.

[44] T. Deelstra, H. Girardet "Urban Agriculture and Sustainable Cities" In Bakker N., Dubbeling M., Gündel S., SabelKoshella U., De Zeeuw H. Growing Cities, Growing Food. Urban Agriculture on the Policy Agenda. Feldafing, Germany: Zentralstelle Für Ernährung Und Landwirtschaft (Zel), P. 4366, 2000. 